Canadian University Music Review

Canadian University Music Review

Revue de musique des universités canadiennes

\title{
Franz Joseph Haydn and the Five-Octave Classical Keyboard: Registral Extremes, Formal Emphases and Tonal Strategies
}

\section{James S. MacKay}

Volume 23, numéro 1-2, 2003

URI : https://id.erudit.org/iderudit/1014521ar

DOI : https://doi.org/10.7202/1014521ar

Aller au sommaire du numéro

\section{Éditeur(s)}

Canadian University Music Society / Société de musique des universités canadiennes

ISSN

0710-0353 (imprimé)

2291-2436 (numérique)

Découvrir la revue

Citer cet article

MacKay, J. S. (2003). Franz Joseph Haydn and the Five-Octave Classical Keyboard: Registral Extremes, Formal Emphases and Tonal Strategies. Canadian University Music Review / Revue de musique des universités canadiennes, 23(1-2), 126-144. https://doi.org/10.7202/1014521ar
Résumé de l'article

Avant environ 1800, les différentes formes d'instruments à clavier classiques (clavecin, clavicorde et pianoforte) comportaient un modeste ambitus de cinq octaves (de deux octaves et demie sous le do central à $f a$ deux octaves et demie au-dessus du do central). Le présent essai analyse comment cet ambitus influe sur le contour tonal de la musique pour clavier de Joseph Haydn, écrite après 1765. L'auteur démontre comment Haydn utilisait les extrémités du registre pour mettre en relief les principaux points de jonction formels, les cadences et les modulations importantes. Enfin, il signale comment la présence ou l'absence des hauteurs extrêmement graves ou aiguës du clavier contribue à accentuer le caractère de la tonalité. Pour ce faire, il étudie différents contextes dans lesquels Haydn les emploie : ré mineur, do majeur et la majeur.
All Rights Reserved @ Canadian University Music Society / Société de musique des universités canadiennes, 2004
Ce document est protégé par la loi sur le droit d'auteur. L’utilisation des services d'Érudit (y compris la reproduction) est assujettie à sa politique d'utilisation que vous pouvez consulter en ligne.

https://apropos.erudit.org/fr/usagers/politique-dutilisation/ 


\title{
FRANZ JOSEPH HAYDN AND THE FIVE-OCTAVE CLASSICAL KEYBOARD: REGISTRAL EXTREMES, FORMAL EMPHASES AND TONAL STRATEGIES ${ }^{1}$
}

\author{
James S. MacKay
}

\section{INTRODUCTION}

Haydn's active period as a composer (ca. 1750-1803) was an interesting time of transition for keyboard composition, in which the nature of keyboard writing (and even the instruments themselves) was distinctly in flux. The popularity of the clavichord and harpsichord, the instruments of choice during the Baroque era, was on the wane, due to the ascendancy of the fortepiano. One aspect that these instruments all shared, which undoubtedly affected the way Haydn and his contemporaries wrote for them, was their modest range in comparison with the modern keyboard. In the second half of the 18th century, keyboard instruments gradually became standardized as to their range: by the 1760 s, composers could quite reliably count upon a five-octave range from the $\mathrm{F}$ which is two and a half octaves below middle $C$ to the $F$ two and a half octaves above it (FF to $f^{3}$ ). This registral span, with a few exceptions around the turn of the century (especially in England, where fortepianos with extended range were common in the 1790s), ${ }^{2}$ set the boundaries for most keyboard music published during the first half of the Classical period.

Unlike Beethoven, whose early keyboard works often strain against the registral limits of the instruments of his time, as Charles Rosen points out (Rosen 1997, 509), Haydn's keyboard music seems to display satisfaction with the boundaries set by the instruments for which he composed. Especially in his later years, his keyboard writing illustrates his efforts to use the entire fiveoctave range of his time in an imaginative manner. Rather than struggling against his keyboard instruments' registral limits, Haydn sought to turn this seeming constraint to musical advantage. As Charles Rosen has noted:

One of the chief advantages of using an early piano [an authentic Classical keyboard instrument] is that the public can appreciate the way Haydn ... used the upper and lower limits of the keyboards for the most powerful climaxes.

1 A shorter version of this paper was read at the Canadian University Music Society annual meeting, Quebec City, 2001. I would like to thank Dr. William Horne and the anonymous reviewers for making valuable suggestions on earlier drafts.

2Edwin Good (2001, 70, 98-100) has noted that instruments with upward extensions to $G$ and $A$ were occasionally found in 1780s Vienna, but the impetus for extending keyboard range largely began with Broadwood in England around 1791. 
The visual effect of performance on old instruments may seem a trivial point, but the dramatic effect of striking the highest or lowest note on the keyboard was an essential part of the musical structure. (Rosen 2000, 210; material in square brackets added by author)

Thus, Rosen suggests that Haydn took into account the medium for which he composed, using the registral profile of his keyboard instruments to articulate form. This pairing of registral extremes and significant formal events has a visual component, as Rosen states, but more importantly, may audibly influence how listeners perceive a sequence of musical events. Ernst Oster, for instance, describes how registral extremes can create an audible link between temporally separate musical events, an abstract Urlinie that controls the shape of a musical composition (Oster 1961, esp. 56-57 and 71). Virtually uniquely among instruments, keyboards have a fixed upper range; thus, the Classical keyboard's uppermost $\mathrm{F}$ could be given a particularly vital role in creating such links, and thereby articulating form and musical content. Similarly, the keyboard's lowest F, though less salient than the uppermost $\mathrm{F}$ due to its register, could play a comparable role. This essay seeks to explore what role the Classical keyboard's registral limits play in Haydn's compositional decision-making, examining his keyboard works for evidence of this mapping of form and extreme register.

Haydn, likely more than Mozart and Beethoven, relied upon the keyboard as a source of musical inspiration. He acknowledged to Karl Griesinger, his first biographer, that he got ideas for his compositions by improvising (phantasieren) at the keyboard (Brown 1986, 5). This tactile approach to composition, through which Haydn was physically confronted with his keyboard instruments' range limitations each time he sat down to write, ought to have had some influence on how and where he introduced registral extremes in his music. It follows that, as Rosen asserts, Haydn would give these extreme pitches special treatment, using them to add emphasis to a musical event in a composition.

This aspect of Haydn's use of register, however, developed gradually during his early years as a composer. He was careful not to put undue emphasis on registral extremes in his earliest keyboard works; in fact, deliberate de-emphasis of such extremes seemed to be his musical aim. As Zohar Eitan observes, concerning Haydn's keyboard music written up to 1765 : "Rather than aligning [melodic] peaks with other emphatic phenomena such as metric and durational accents ... Haydn frequently associates them with weak metric placement or short duration" (Eitan 1997, 52). Eitan implies that Haydn's treatment of extreme register differs in the music he composed from 1766 onward (after his move to Esterháza), though as this repertoire was outside the scope of his study, he doesn't pursue this hypothesis further (Eitan 1997, 33n1).

As a complement to Eitan's study, we will examine Haydn's use of registral extremes in selected works for piano solo and piano trio written after about 1765, focusing primarily on his compositions of 1784-95, the period in which he turned definitively to the fortepiano as his primary keyboard instrument. ${ }^{3} \mathrm{We}$

3László Somfai $(1995,29)$ sets this boundary at 1780 , after the Auenbrugger sonatas (Hob. XVI: 20 and 35-39) that display mixed signals as to their intended instrument. 
will explore how Haydn incorporates the keyboard's registral extremes into his large-scale tonal planning, either by using them to highlight major formal junctures in a composition, to emphasize important phrase-level events, such as cadences and modulations, or to call attention to musically significant or unusual individual harmonies. Finally, since this pitch-class lies differently in relation to the tonic in each tonality, we will examine how the presence and location of the keyboard's registral extremes contribute to key character, an issue that has not hitherto been explored in the literature.

\section{I}

We will preface our discussion with a brief overview of the classical keyboard during the second half of the 18th century. One cannot truly speak of a single "classical keyboard" during Haydn's time: the harpsichord, clavichord and fortepiano all exerted some influence on his keyboard writing. Moreover, their range varied from one instrument to another: the standardization of keyboard range lay well in the future, not occurring until well into the 19th century. Five-octave instruments, though not uncommon during Haydn's early years, were far from being the norm. Moreover, certain chromatic notes in the low register were often absent in smaller keyboards, complicating musical decisions in the left hand of keyboard compositions (Libin, 1994, 8-21). Though Haydn's keyboard music assumes a five-octave range fairly early on (the Esterházy Sonatas of 1773 , his first keyboard publication, employ the $\mathrm{FF}-\mathrm{f}^{3}$ range typical of classical keyboard instruments, and certain of his works from the 1760s likewise require this range), this range was not universally available at the time of composition. Clavichords especially, due to their compact size, tended to be more modest in range during this era (extending downward only to the $\mathrm{C}$ below the bass staff), though Hieronymous Albrecht Haas built a fully chromatic five-octave clavichord $\left(\mathrm{FF}-\mathrm{f}^{3}\right)$ as early as 1742 (Libin 1994, 16). Mid-century harpsichords tended to span five full octaves, but their range varied (either FF- $\mathrm{f}^{3}$ or GG- $\mathrm{g}^{3}$ was possible). A number of Domenico Scarlatti's harpsichord sonatas have $\mathrm{g}^{3}$ as uppermost pitch; thus, the $\mathrm{f}^{3}$ upper limit was occasionally exceeded, even during Haydn's early years as a composer (Libin 1994, 12). Katalin Komlós has noted that fortepianos from the 1760s typically extended upward to $\mathrm{f}^{3}$ and down to FF (though lacking the bottom F-sharp in some models), at which point the five-octave standard, the norm until ca. 1790, was achieved (Komlós 1995, 20). To be certain, Haydn did not count upon having this extended range in his earliest keyboard works. His works written before ca. 1765 display a more modest upper range, seldom reaching past $d^{3}$, the upper limit common in the keyboard music of J.S. Bach (Libin 1994, 12). Whether this was the limit of his own keyboard or not is a matter of conjecture: none of the instruments with which Haydn composed during these years (other than certain church organs, which are not relevant to the repertoire under consideration) have survived to the present day (Brown 1986, 136-40).

In any event, Haydn began using high and low $\mathrm{F}$ in his keyboard music around 1765, suggesting the acquisition of (or at least access to) a keyboard instrument that possessed what would become the standard late 18th century five-octave range. Though Georg Feder postulates that Haydn's use of this 
extended keyboard range postdates the fire of 1768 that consumed his living quarters (presumably forcing him to acquire a new keyboard instrument, which included these additional notes), certain of his works from before that date already do contain these registral extremes (Brown 1986, 113). ${ }^{4}$ For example, of Haydn's works from the mid-1760s that we can date with certainty (on the basis of dated autographs in his own hand) (Brown 1986, 119 and 131), his sonatas in E-flat major (Hob. XVI: 45, 1766) and D major (Hob. XVI: 19, 1767), and his Capriccio in G major ("Acht Sauschneider müssen seyn," Hob. XVII: 1, 1765) all include low F, though none of them extend upward beyond $\mathrm{d}^{3}$. It is also interesting to observe that Hob. XVI: 19 , in spite of its use of low F, pointedly avoids low F-sharp and G-sharp in its middle movement; ${ }^{5}$ A. Peter Brown has speculated that this work, and a number of others from the mid-to-late 1760 s, were written for a "broken octave" keyboard, where, for example, the rarely-used C-sharp and D-sharp in the keyboard's lowest octave would sound the more musically useful F and G below instead (Brown 1986, 160). These works probably represent an experimental, transitional phase in Haydn's keyboard output, in which he tailored his music to a specific instrument or instruments that he had on site at Esterháza.

The period 1774-1780 saw the circulation of three sets of Haydn keyboard sonatas. While the Esterházy sonatas of 1773 (published 1774) use idiomatic harpsichord figuration (as Brown [1986, 161-65] convincingly argues), the later sets of 1776 and 1780 are more mixed in style, permitting performance on any of the keyboard instrument types that were available at that time (harpsichord, clavichord or fortepiano). Regardless of instrument, Haydn seems to assume a fully chromatic five-octave keyboard range to be commonly available among the music-buying public during these years: both low and high $\mathrm{F}$ occur frequently in all three sets (along with the low F-sharps and G-sharps that were conspicuously absent from the sonatas of the late 1760s).

This range limit remains constant in the 1780 s, as Haydn gradually shifts his allegiance from the harpsichord and clavichord to the fortepiano. (Though he was cool toward the Walter fortepianos of late 18 th century Vienna, his approval of the instruments of Wendel Schanz is apparent from documentary evidence. ${ }^{6}$ ) Even after Haydn was introduced to English grand fortepianos with extended range during his first London trip of 1791-92 (Broadwood \& Co. began manufacturing fortepianos that extended upward by a fifth to $\mathrm{c}^{4}$ in the early 1790s [Rowland 1999, 283]), he continued to write keyboard music that conformed to the five-octave continental European norm: only the Finale of his Sonata in C major (Hob. XVI: 50), likely written during his second London visit of 1794-1795, makes use of these "additional keys" in the upper register,

4Brown does comment, however, that Feder's hypothesis cannot be accepted without reservation. 5Haydn's Sonata in A-flat major, Hob. XVI: 46 (composed ca. 1767-68, according to Brown 1986,123 ), likewise was written for an instrument that had gaps in its lowest octave, judging from some awkward bass register leaps in the finale.

6 Cf. Somfai 1995, 12-13.

7 It should be added that when Haydn played the fortepiano solo from the Finale of his Symphony no. 98 (1792) he apparently used $\mathrm{g}^{3}$, according to Salomon's quintet version, published in 1798 . The 
extending upward by a third to $\mathrm{a}^{3}$. (This work was composed as a gift for Therese Jansen-Bartolozzi, who apparently owned an English grand fortepiano with extended upper range; its publication around 1800 was not Haydn's doing [Brown 1986, 53].)

Though the FF $-\mathrm{f}^{3}$ keyboard range that Haydn began to use in the mid-1760s was virtually the widest range available at that time, it became an arbitrary (and slightly restricted) limit to which he continued to adhere in his later years, in spite of his knowledge of English keyboards with extended range. As László Somfai notes: "almost all works by Haydn, excepting one single London movement [Hob. XVI: 50, Finale, as noted above] can be performed on a keyboard with a range of five octaves $\left(\mathrm{FF}-\mathrm{f}^{3}\right)$ typical of Continental [European] instruments up to the end of the 18th century" (Somfai 1995, 27). Haydn's decision to limit himself registrally made perfect business sense: it would not have been logical for him to write keyboard works that were unplayable on the majority of non-English instruments. Certainly, Haydn seems to have accepted the five-octave limit to which he was accustomed without much difficulty in his keyboard works of the 1790s. Granted, as with many of Beethoven's keyboard works, there are occasional passages that would seem to benefit from an extended upper range (his Piano Trio in F-sharp minor, Hob. XV: 26, first movement, seems to suggest the need for an high F-sharp in bar 88 to preserve the contour of a recurring melodic turn figure in the upper register), but Haydn's keyboard compositions can generally be performed as published, with little loss in musical effect. There is seldom any sense of strain against the keyboard instruments' boundaries; rather, there is an effort to fill this registral space in as interesting and idiomatic a fashion as possible.

\section{II}

We will now examine how Haydn uses the Classical keyboard's lowest and uppermost $F$ to shape tonal decisions at various levels of structure. We will consider how he uses registral extremes to signal the onset of thematic regions, or to accentuate tonal processes such as modulation and closure. This use of register can help to articulate large-scale form: Haydn's prominent use of the keyboard's registral extremes to emphasize important thematic or tonal moments in the musical discourse can assist a listener's perception of a work's formal design.

The fragmentary Sonata in D major (Hob. XIV: 5, recte XVI: 5a) is likely the earliest Haydn keyboard work to contain both high and low F. The exact year of composition is unknown (the autograph's title page, which would have included this information, is missing), but Christa Landon's assertion that this work predates the E-flat major sonata (Hob. XVI: 45,1766 ) is quite reasonable, for stylistic reasons (Haydn 1966a, 134). ${ }^{8}$ Already, at this early date, we see

published score, though, extends upward only to the customary $\mathrm{f}^{3}$. This passage, "which Dr. Haydn used to play," is reproduced in Haydn (1966b, xxvi). If Salomon remembered correctly (he was a first-hand witness at the premiere), this symphony would be among the earliest works to use the English fortepiano's extended range in a public venue.

$8 \mathrm{H}$. C. Robbins Landon $(1978,336)$ comments that Haydn's calligraphy suggests that the work could have been written as early as 1765 . Brown's suggested later date of ca. 1767-68, probably due to the work's five-octave range (Brown 1986, 123) seems less tenable to the current author. 
Haydn's awareness of how extreme pitches can assist in creating emphasis of important formal and tonal events. These pitches occur in the $\mathrm{D}$ minor section of the second movement, a stormy trio that stands in stark contrast to the amiable minuet that precedes it. Both registral extremes are introduced in a striking manner in this passage. As shown in example $1 \mathrm{a}$, the low $\mathrm{F}$ concludes the theme's opening two-measure gesture. (It also returns with the goal chord of the section's final cadence, as shown in example $1 \mathrm{c}$.) As evidenced by example $1 \mathrm{~b}$, the high $\mathrm{F}$ adds emphasis to the modulation from D minor to its relative key, F major; it is the goal of an extended ascending scalar passage. Haydn seems to be reveling in the presence of these notes, almost as if they were available to him for the first time. His use of high and low $\mathrm{F}$ in conjunction with important formal or tonal events in the composition is a new idea, standing in direct contrast to his customary attenuation of registral extremes during this relatively early stage of his musical career. Whereas in his early years, according to Eitan, Haydn's use of extreme registers was restrained and conventional (Eitan 1997, 53), this work points ahead to Haydn's later keyboard music, which displays the composer's greater awareness of how register could be employed to clarify a work's formal design.

(a) bars 39-42 (opening phrase of trio section): low F at end of basic idea

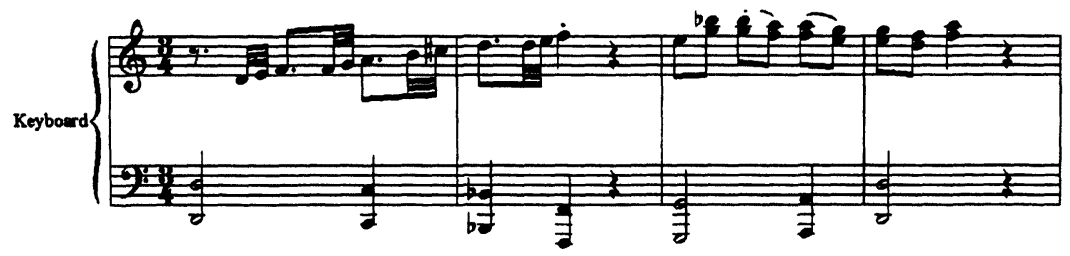

(b) bars 49-53: high $\mathrm{F}$ highlighting modulation to $\mathrm{F}$ major

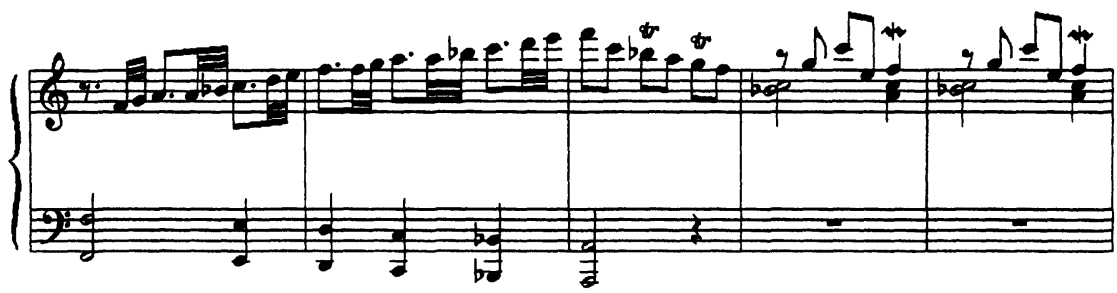

(c) bars 55-60: low F to close first half of form

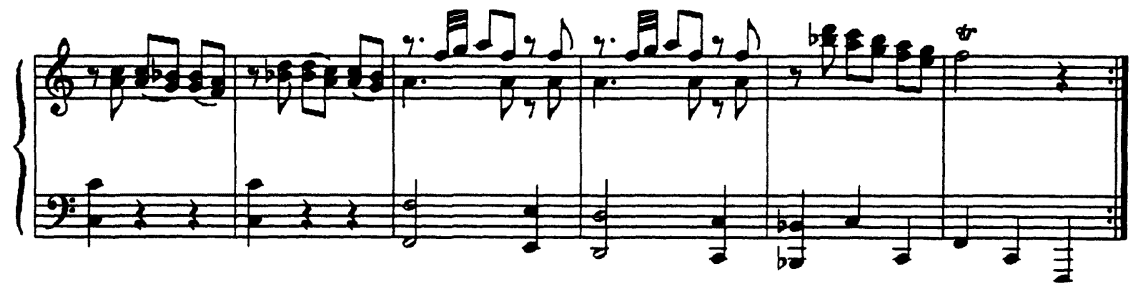

Example 1. Sonata in D major (Hob. XVI: 5a), second movement: use of high and low F 
In his later keyboard works, Haydn often introduces registral extremes to add brilliance to the beginning of a theme. His Piano Trio in B-flat major (Hob. XV: 20, written ca. 1794), first movement, illustrates: this composition, uniquely in his works for keyboard, begins with the continental European keyboard's uppermost $F$. This extreme high pitch, combined with the accompaniment's low range, opens a vast registral space (example 2), and imparts to this theme a bold and distinctive character. Moreover, the frequent return of this pitch later on in the exposition (it appears 14 times in total, playing a

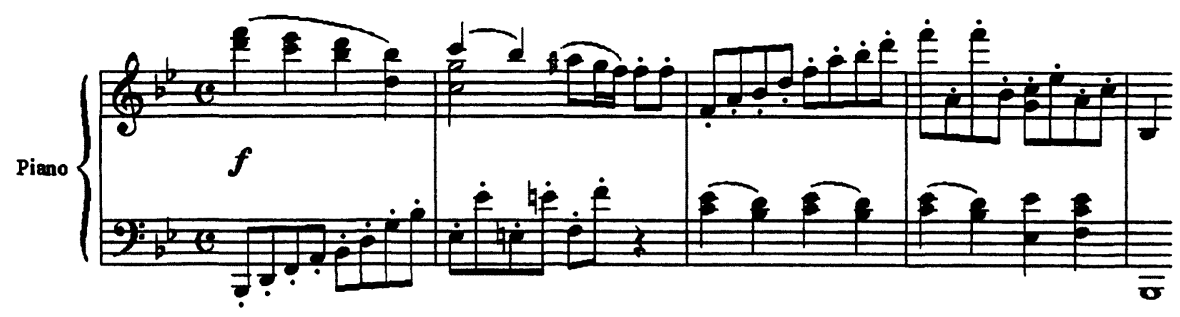

Example 2. Piano Trio in B-flat major (Hob. XV: 20), first movement, bars 1-5 (piano part only): introduction and emphasis of high $\mathrm{F}$ at beginning of main theme

prominent role in the transition and subordinate theme group in addition to the main theme) contributes to the exuberance of the work as a whole. This intensification of musical effect can still be attained if high $\mathrm{F}$ occurs shortly after a composition is underway. For example, Haydn introduces this registral extreme in the opening phrase of his Piano Trio in C major, Hob. XV: 27 (written ca. 1795). As shown in example 3, the main theme begins with a two-bar basic idea that reaches above the staff to $E$. The repetition of this material on the dominant in bars 3-4 introduces $F$ as an abstract upper neighbour to this $\mathrm{E}$, supported by $\mathrm{V}^{7}$ harmony. This pairing of high $\mathrm{F}$ and a mildly dissonant harmony differs from Haydn's practice during his formative years as a composer: Eitan has noted that in early Haydn, "upper notes of tense

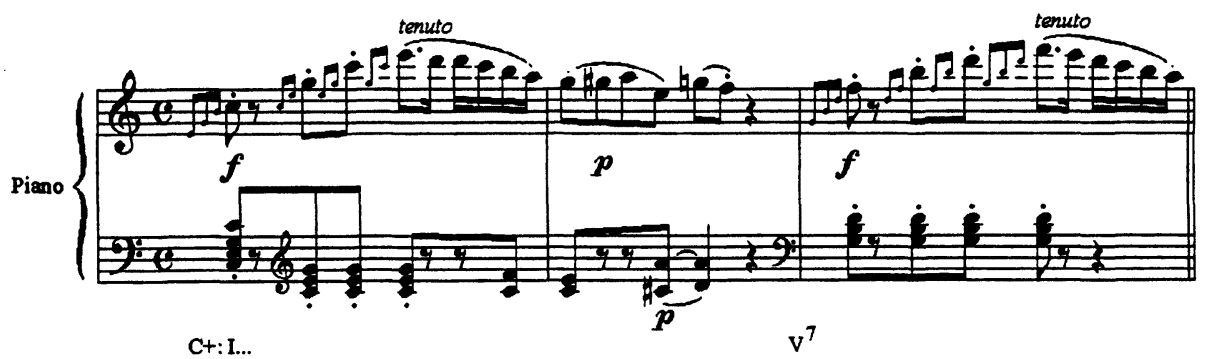

Example 3. Piano Trio in C major (Hob. XV: 27), first movement, bars 1-3 (piano part only): early introduction of high $\mathrm{F}$ as part of dominant seventh harmony 
chords [do not function] as contour peaks" (Eitan 1997, 53). In this work and many others from his late period, however, Haydn does indeed combine high $\mathrm{F}$ with unusual harmonic support on a fairly regular basis (this pairing of high $\mathrm{F}$ and dissonant harmony occurs frequently in D major works, especially, as we will explore below). No longer content to attenuate melodic high points as he had before 1765 , Haydn now seeks to emphasize them instead.

When Haydn avoids high or low F early in a work, he may be holding them in reserve to emphasize a later important formal or thematic event. The finale of his Sonata in E-flat major (Hob. XVI: 52) will illustrate. Registral extremes coincide with the beginning of Subordinate Theme 1 and the middle of Subordinate Theme 2 in this movement (in addition to setting in relief the half cadence in E-flat major at the transition's midpoint, bar 36). As shown in example $4 \mathrm{a}$, the boundary between the transition and the subordinate theme is somewhat blurred by the insistent repeated $\mathrm{F}$ in the right hand. When the unaccompanied repeated $\mathrm{F}$ arrives in bar 44 following the half cadence on the downbeat, we could understand it either as the subordinate theme's onset, or as filler material marking time until this theme arrives. The arrival of high $\mathrm{F}$ in bar 48 , accompanied by a fortissimo dynamic marking and by the first tonic chord of the new tonality (B-flat major), finally signals incontrovertibly that
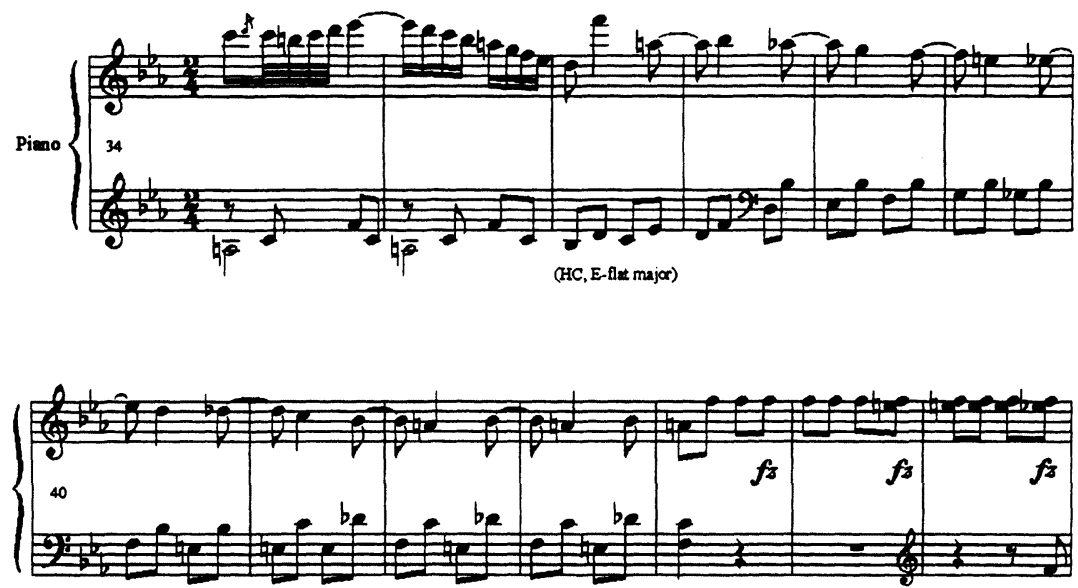

(HC, B-nat major)

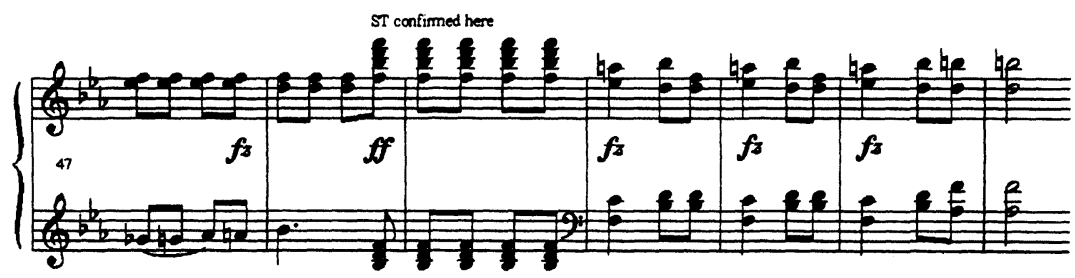

Example 4a. Sonata in E-flat major (Hob. XVI: 52, Finale, bars 34-53: high F bisects transition (bar 36) and confirms arrival of subordinate theme (bar 48) 
the subordinate theme is underway. Here, the high $F$, and its associated seven-voice chord, has a clarifying role. It is not so much a signal of the new formal region as an emphatic confirmation of it.
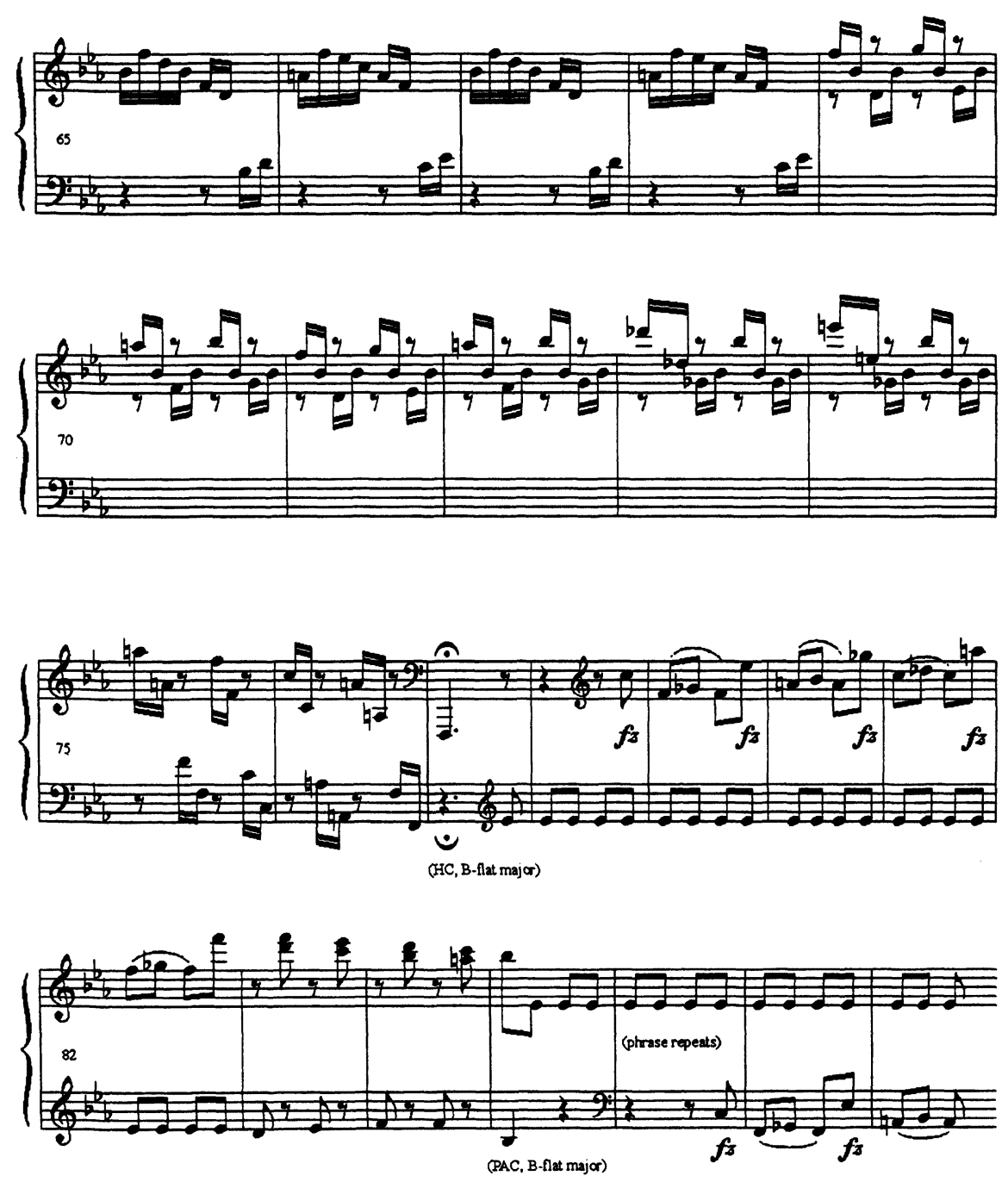

Example 4b. Sonata in E-flat major (Hob. XVI: 52, Finale, beginning of Subordinate Theme 2 (bars 65-88): use of registral extremes to highlight half cadence and authentic cadence

The importance of registral extremes as formal markers continues in Subordinate Theme 2 . As shown in example $4 \mathrm{~b}$, this theme begins with a toccatalike flourish in the upper register, reaching upward to E natural in bar 74 as if to lead to high F. However, Haydn instead counterbalances this gradual ascent 
to the keyboard's upper octave with a rapid descending arpeggio, leading ultimately to low $\mathrm{F}$ in bar 76 , a gesture that sets in relief the half cadence that bisects the theme. When the musical activity resumes, Haydn revisits the upper register, leading upward, through a series of dissonant and jagged melodic gestures, to the high $\mathrm{F}$ that had been suppressed in the preceding phrase. This melodic goal resolves the prominent $E$ natural of bar 74, and adds considerable brilliance to the subordinate theme group's conclusion.

Haydn will occasionally use one of the keyboard's registral extremes to highlight an important moment in a sonata-form development section. In his Piano Trio in D major (Hob. XV: 24, written c. 1795), first movement, Haydn uses high $\mathrm{F}$, supported by $\mathrm{V}^{7}$ harmony in $\mathrm{C}$ major, to introduce a prominent excursion into that key, the first important tonal goal of the development (example 5). Though $\mathrm{F}$ had been introduced and emphasized as part of the triplet accompaniment figuration prior to its appearance in the melody, its transfer into the upper register makes it all the more salient. Moreover, this is the first high $\mathrm{F}$ to appear in the work: the withholding of the keyboard's highest pitch until this late stage in the movement surely creates a different registral and dynamic contour than we observed in the Trio in B-flat major (Hob. XV: 20) discussed above, where this pitch is prominent from the outset.
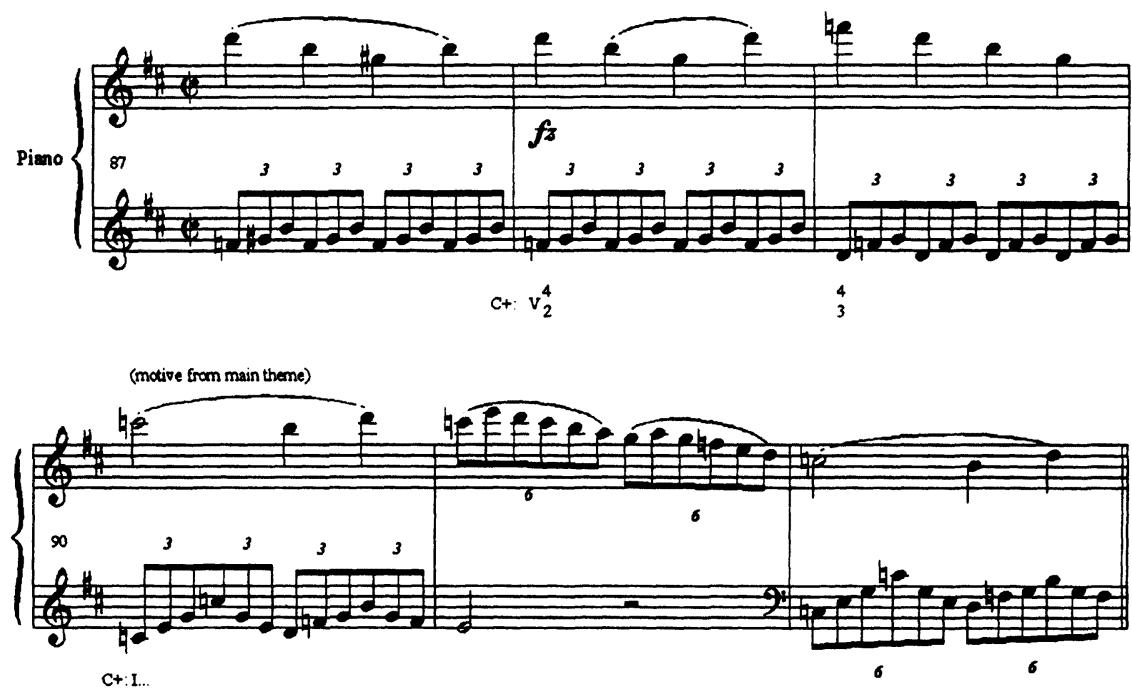

Example 5. Piano Trio in D major (Hob. XV: 24), first movement, bars 87-92 (piano part only: use of high $\mathrm{F}$ in development during modulation to $C$ major 
An important goal of most development sections is the dominant pedal that prepares the return of opening material to begin the recapitulation. Haydn emphasizes this formal juncture with the keyboard's registral extremes in one of his last keyboard works, the Sonata in C major (Hob. XVI: 50). The opening movement's development section ends with a fortissimo V7 chord in dense eightpart texture, with the keyboard's uppermost F prominently on top (example 6). Though this extreme pitch occurs frequently at earlier stages in the work, including a remarkable instance midway through the development, where it prepares a modulation to the remote key of A-flat major, its emphatic return at this formal location, coupled with textural density, mildly dissonant harmony and a loud dynamic level, makes its reappearance particularly significant in this passage. Furthermore, this gesture that highlights high $\mathrm{F}$ is set apart effectively from the subsequent return of the main theme, which is characterized by low register, staccato articulation and thin texture. Moreover, Haydn is so intent on emphasizing high $\mathrm{F}$ that he breaks away from the descending third motive with which he had saturated the preceding two measures, even though repeating this motive in the uppermost octave would have led more logically to the recapitulation's initial C in the melodic line. Haydn's abandonment of his motivic material increases the disruptive effect of the high $\mathrm{F}$ in this passage.

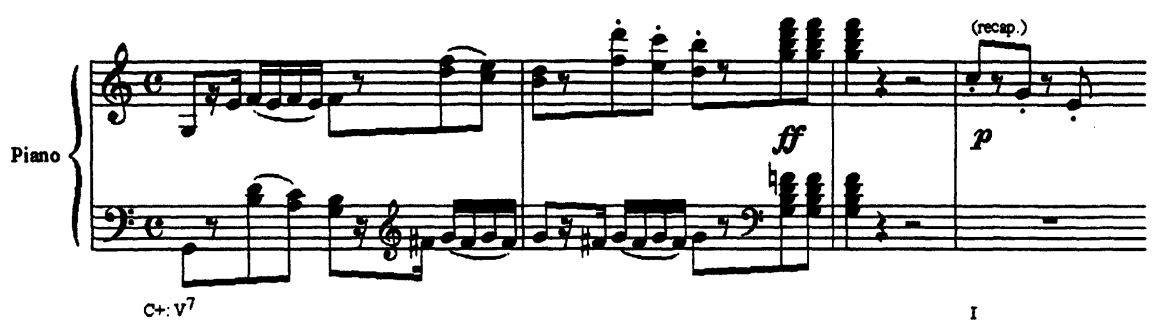

Example 6. Sonata in C major (Hob. XVI: 50), first movement, bars 99-102; high F at end of development

\section{III}

We will now examine passages in which Haydn emphasizes a point of closure and/or modulation through the use of extreme register. There is a precedent for this device in the music of his friend and colleague, Mozart: in the opening movement of his Sonata in B-flat major, K. 333, Mozart withholds the work's first high $\mathrm{F}$ until the beginning of the cadential progression that closes the subordinate theme in the exposition, thus confirming incontrovertibly the dominant tonality. As Charles Rosen notes, such passages display the influence of instrumental virtuosity on the compositional process (in this case, specifically invoking concerto style), and impart brilliance to a conventional formal moment (Rosen 1997, 71-72). Though Mozart, who premiered most of his concertos himself, could almost be expected to allow performance considerations to influence his compositional decisions, it might be a bit more surprising that Haydn, "not a wizard on any instrument," as he himself modestly claimed (Brown 1986, 3), thought in much the same manner when he composed for the 
keyboard. Certainly, though, virtuosity is a major part of the musical discourse in the keyboard trios from Haydn's London period, as these works were designed to challenge the best amateur keyboardists of that era (1790s London was especially known for its fine performers on the fortepiano). The opening movement of his Piano Trio in G minor (Hob. XV: 19, written ca. 1794), illustrates Haydn's new attention to brilliant and idiomatic keyboard writing as a means of intensifying the musical effectiveness of a passage. As shown in example 7, the melodic line of the opening theme's consequent phrase (bars 7-12) arches gracefully upward until it reaches the uppermost $F$ to coincide with the work's first perfect authentic cadence (the harmony supporting this pitch is a cadential six-four chord in B-flat major). The melodic line's graceful ascent, counterbalanced by the precipitous drop following this pitch's arrival, effectively dramatizes the move to the major mode. The prominent $\mathrm{F}$-natural, replacing the home key's leading tone ( $\mathrm{F}$-sharp), confirms, through registral emphasis, the theme's departure from $G$ minor.

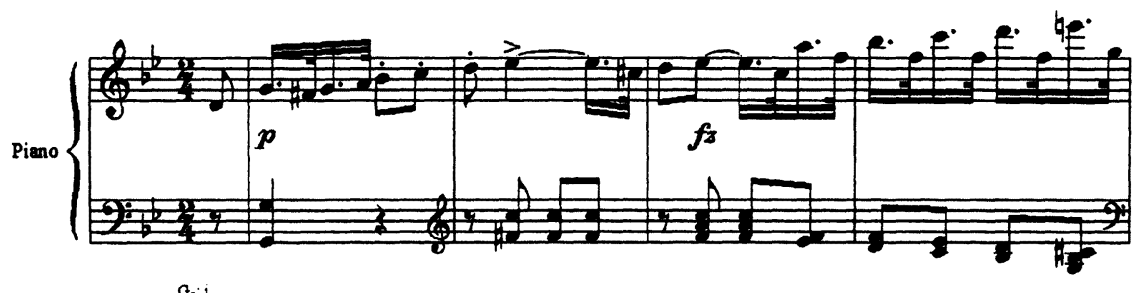

Q.: 1

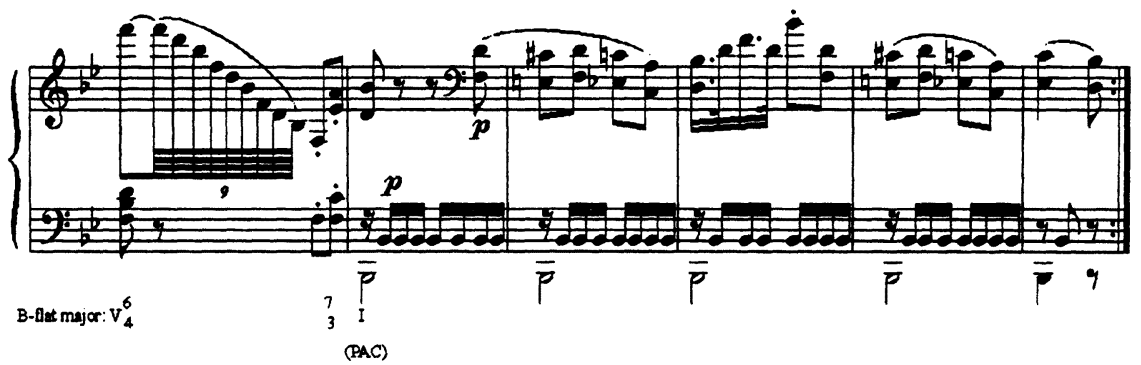

Example 7. Piano Trio in G minor (Hob. XV: 19), first movement, bars 6-16 (piano part only): uppermost $\mathrm{F}$ highlights cadence

This new emphasis on virtuosity informs Haydn's use of register in a passage from the opening movement of his Sonata in E-flat major (Hob. XVI: 52) as well. As in the preceding example, Haydn uses extreme pitches to highlight an important moment of closure (example 8). The progression that leads to the subordinate theme's final cadence in the exposition begins with a forte outburst on a cadential six-four chord in the subordinate key, B-flat major (since this chord follows a quiet, tonally ambiguous passage in octaves, the gesture comes as a major surprise). Haydn stretches out this harmony for nearly a full measure, with a rumbling tremolo incorporating low $\mathrm{F}$ in the left hand 
throughout, while the right hand arches upward in dense four-voice chords to high $\mathrm{F}$. This explosive passage is clearly meant to create as much noise as possible, as Haydn fills the keyboard's five-octave space with particularly dynamic musical material (though not indicated in the score, the use of the damper pedal to create a wall of sound would certainly not have been out of place). By combining both high and low $\mathrm{F}$ with a clear harmonic signal of closure, Haydn uses registral extremes to impart drama to a conventional formal moment.
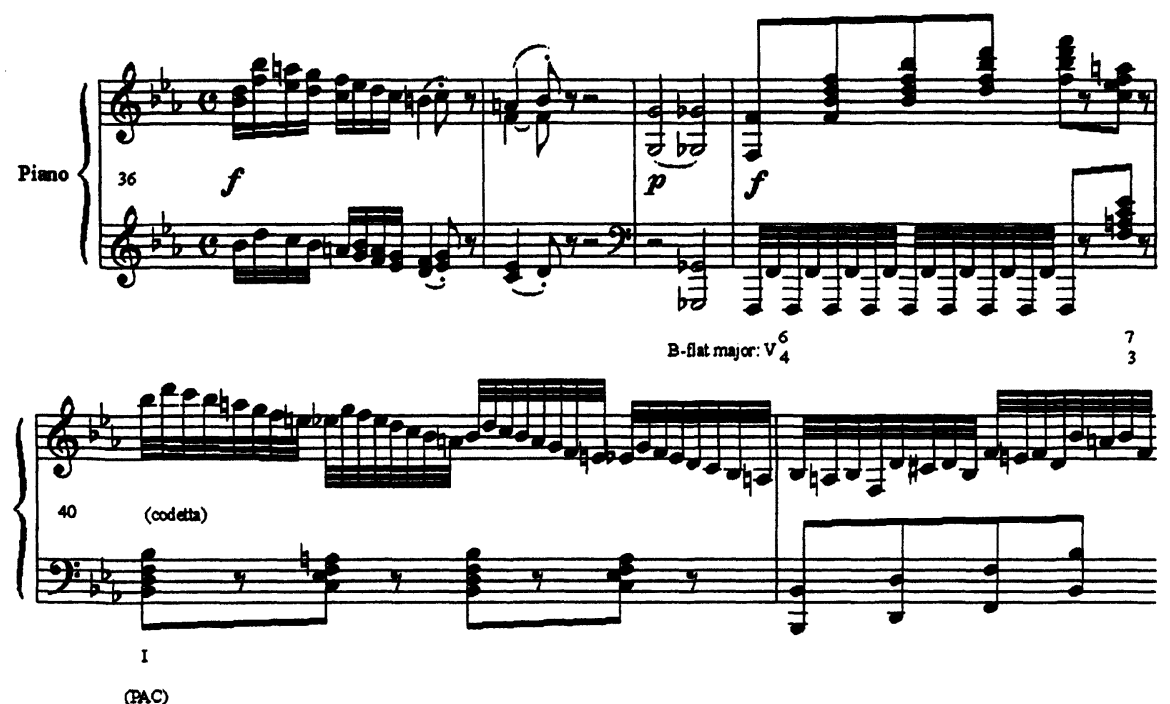

Example 8. Sonata in E-flat major (Hob. XVI: 52), first movement, bars 36-41: use of registral extremes at conclusion of subordinate theme group

In the preceding two examples, high $\mathrm{F}$ supports an important diatonic chord in the new tonality. In other passages, Haydn pairs the keyboard's registral extremes with striking harmonies to signal an impending modulation. One observes this technique as early as his Sonata in B-flat major (Hob. XVI: 18), written ca. 1766-73 (Brown 1986, 120). In the opening movement, Haydn introduces the work's first high $\mathrm{F}$ (bar 17) as a dissonance within $\mathrm{V}^{4}{ }_{2}$ of the new tonality. ${ }^{9} \mathrm{He}$ then reiterates the pitch on the following beat, this time with the tonic chord of $\mathrm{F}$ major as harmonic support (and subsequently repeats this entire gesture in the next bar for additional emphasis). The prominent high $\mathrm{F}$ contributes to Haydn's forceful confirmation of the subordinate tonal region, F major, as the transition concludes (example 9). The concluding minuet from Haydn's Piano Trio in F major (Hob. XV: 6, 1785) displays a similar pairing of registral extremes and chromatic harmony. W. Dean Sutcliffe has noted that both extreme register (the keyboard's uppermost F) and tone colour (the cello's open

9Older editions (Passler and Peters) include a high F earlier in the transition (bar 12), but this note is spurious (compare Henle and Wiener Urtext editions). 
G string) contribute to an effective emphasis of the dominant tonality, $\mathrm{C}$ major (example 10). As Sutcliffe remarks, "The colouristic value of the [cello's] G lies in its registral complementation of the keyboard's highest note, $\mathrm{f}^{3}$, the most poignant moment of the section" (Sutcliffe 1998, 264). As a result, this important chromatic chord ( $\mathrm{V}^{7}$ of $\mathrm{C}$ major), and the brief emphasis of $\mathrm{C}$ major tonality that it initiates (bars 11-12 function as an imperfect authentic cadence in this key), acquires a greater degree of prominence within the musical flow. A moment in the composition that could have been commonplace (a move from F major to its dominant) becomes, through careful use of register, "the most poignant moment" within the form.
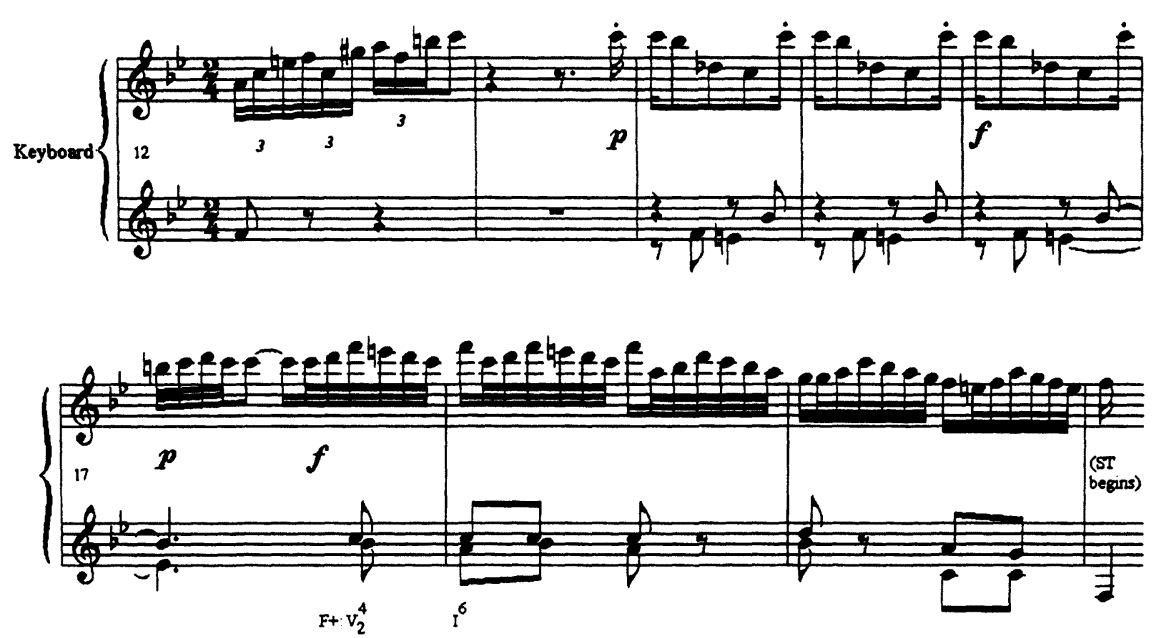

Example 9. Sonata in B-flat major (Hob. XVI: 18), first movement, bars 12-20: high F confirms arrival of $\mathrm{F}$ major

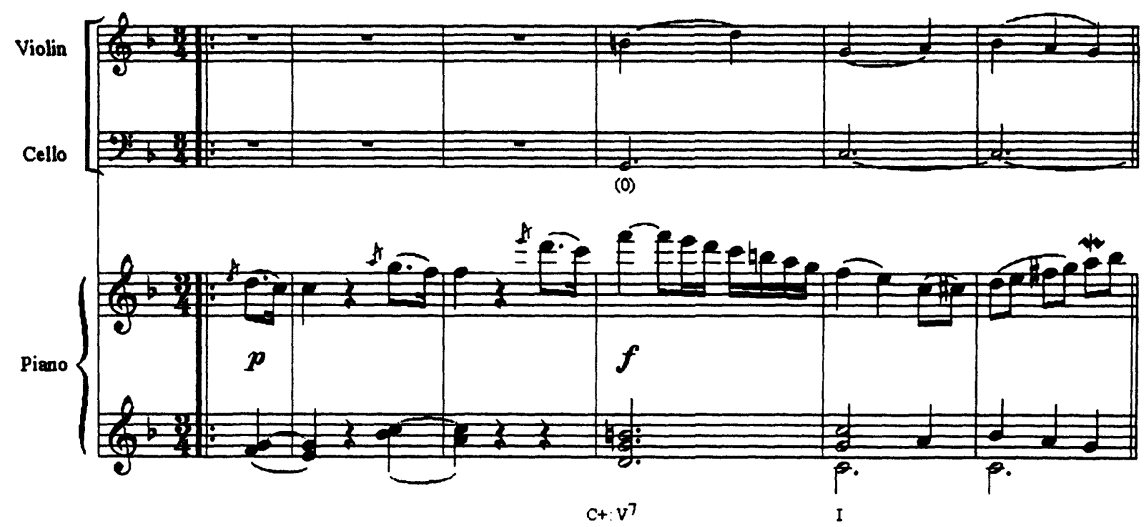

Example 10. Piano Trio in F major (Hob. XV: 6), Finale, bars 8-13: complementation of piano's high $F$ and cello's open $G$ 
As has been implicit in the preceding discussion, one possible consequence of Haydn's mapping of the keyboard's uppermost or lowest $F$ onto particular harmonies within a key is that individual tonal regions can then take on a subtly different sound from each other. In other words, Haydn's use of registral extremes can and does contribute to a sense of key character. For example, many of the passages discussed above involve $\mathrm{V}^{7}$ of $\mathrm{C}$ major: where this chord lies in the tonality of the movement may determine where and how in the form a high or low F might occur. We will explore this notion of key character in three different tonalities: $\mathrm{D}$ minor, where $\mathrm{F}$ is a member of the tonic chord; $\mathrm{C}$ major, where $\mathrm{F}$ is in the diatonic scale, but not in the tonic chord; and A major, where $\mathrm{F}$ is non-diatonic, and thus can only arise though modulation or modal mixture. As the Classical keyboard's registral extremes lie differently with respect to the tonic in each of these three keys, one would expect Haydn's use of it to be distinctive in each of them. The ensuing discussion will explore this differentiation of usage.

In the key of $D$ minor, though Haydn would be able to introduce $\mathrm{f}^{3}$ as a member of a diatonic harmony, he seldom does so. Instead, he prefers to introduce high $\mathrm{F}$ as part of an augmented sixth chord, or other exotic harmony. This is Haydn's procedure in the opening movement of his Piano Trio in D minor (Hob. XV: 23, ca. 1794). This variation movement in andante tempo rotates two themes, the first one in $\mathrm{D}$ minor, the other in $\mathrm{D}$ major. Though Haydn could have introduced high $\mathrm{F}$ rather early in the movement with stable harmonic support (as it is a member of the tonic chord), he chooses instead to hold it in reserve until the theme's climactic moment (example 11). A German augmented sixth chord, with high $\mathrm{F}$ on top, begins the cadential progression that terminates the theme. Thus, as in the Piano Trio in F major (Hob. XV: 6), Haydn reserves this high pitch to emphasize a striking harmony at a key moment in the musical discourse.

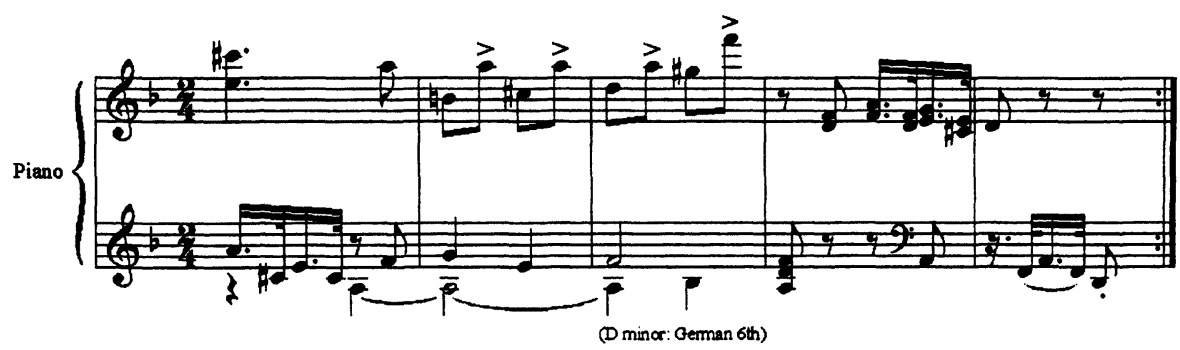

Example 11. Piano Trio in D minor (Hob. XV: 23), first movement, bars 16-20 (piano part only): high $\mathrm{F}$ as part of augmented sixth sonority 
Interestingly, the $\mathrm{D}$ major theme with which this minor-mode theme alternates never uses the high $F$ (the range of this theme extends upward only to $E$ ). Granted, high $\mathrm{F}$ is more problematic in D major (in which it could only appear as part of a chromatic chord such as an augmented sixth or viio7 of $\mathrm{V}$, or by modal mixture) than it is in D minor, where it is a member of three diatonic triads: tonic, submediant and subdominant. However, the avoidance of high $\mathrm{F}$ in the D major sections of this movement seems to be a deliberate choice on Haydn's part, guaranteeing that the movement's two themes, both in their initial statements and in their subsequent variations, are set apart from each other not only by mode, but also by their registral profile. ${ }^{10}$

The particular sound of Haydn's C major tonality is perhaps the most striking example of how the use of registral extremes can help to define tonal character. Typically, Haydn includes high $\mathrm{F}$ fairly early on in his $\mathrm{C}$ major compositions, most often supported with $\mathrm{V}^{7}$ harmony, ${ }^{11}$ as we saw in the Piano Trio in C major (Hob. XV: 27), first movement (see example 3, above). Even when Haydn withholds this pitch until later in the movement, as in the Sonata in C major (Hob. XVI: 50), presented above as example 6, the harmonic support is frequently $\mathrm{V}^{7}$. This pairing of the keyboard's uppermost note and mildly dissonant harmony adds a modicum of brilliance and bite to Haydn's $\mathrm{C}$ major tonality. (Interestingly, C major is Haydn's "festive" key in his symphonies (Robbins Landon 1976, 541-42), though here, it is orchestration-the presence of trumpets and high horns-rather than register per se that contributes to this brilliance.)

Finally, we will consider Haydn's use of high F in A major, a tonality in which the Classical keyboard's registral extremes are not part of the diatonic scale, and thus can only arise through chromaticism, modal mixture or modulation. (One might recall that in D minor, Haydn often uses high $\mathrm{F}$ as part of chromatic harmonies as well, but in that key, such a treatment of this registral extreme is a matter of choice; in A major, it will be out of necessity.) For example, in his Sonata in A major (Hob. XVI: 26, one of the Esterházy sonatas of 1773), there is a lone high $\mathrm{F}$ : it appears midway through the first movement's recapitulation, the result of a 5-6 motion from $E$ to $F$ natural in the upper voice over an $\mathrm{A}$ in the bass (example 12a). Therefore, Haydn introduces the keyboard's uppermost pitch through a modal shift to the parallel minor, an intriguing colouristic device that enhances the prominence of this registral extreme.

10Though we have a relatively small sample of $\mathrm{D}$ minor works (or sections of works) with which to determine Haydn's registral procedures, this pairing of high $\mathrm{F}$ and chromatic harmony is not atypical. In his Piano Trio in D major (Hob. XV: 7, composed 1785), third movement, bar 19, Haydn reserves high $\mathrm{F}$ for a cadential moment in the minore middle section, supported (as in Hob. XV: 23), by a German augmented sixth chord.

11 Though IV, ii and viio are also possible diatonic contexts for $\mathrm{F}$ in the key of $\mathrm{C}$ major, Haydn uses these harmonies far less frequently than $\mathrm{V}^{7}$ as support for this registral extreme. 


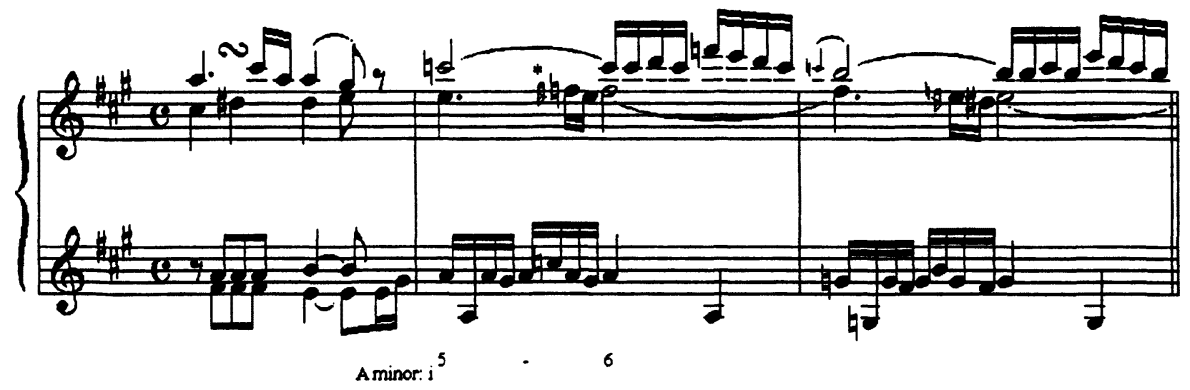

Example 12a. Sonata in A major (Hob. XVI: 26), first movement, bars 64-66: high F resulting from modal mixture

* So in Henle and Wiener Urtext editions; Breitkopf and Peters add a natural to the G.

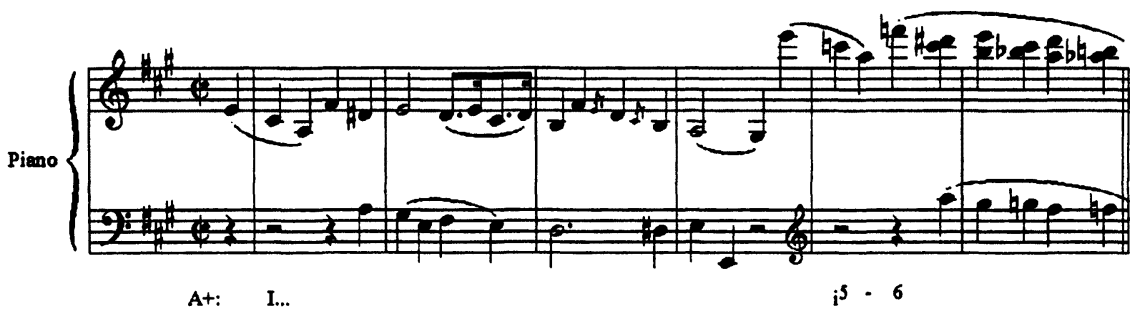

Example 12b. Piano Trio in A major (Hob. XV: 18), first movement, bars 150-56 (piano part only): high $\mathrm{F}$ resulting from modal mixture

Haydn's Piano Trio in A major (Hob. XV: 18), first movement, written two decades after Hob. XVI: 26 , shares with it a nearly identical treatment of high $\mathrm{F}$, as illustrated by example $12 \mathrm{~b}$. The registral extreme occurs late in the recapitulation (early in the consequent phrase of the subordinate theme), supported by the same modal shift and 5-6 motion that we had seen in Hob. XVI: 26. The chromatic sequence that winds downward from the high $\mathrm{F}$ also models on the earlier work, though in the passage from the piano trio, the chromaticism is more pervasive and the harmonic changes more rapid. This thematic unit is further distinguished from its immediate surroundings by its "music box" style: the passage is thin-textured, and both hands lie in the keyboard's uppermost octave. Thus, it is not merely the presence of the high $\mathrm{F}$ alone, but the extended use of the keyboard's upper register throughout the passage that sets this material apart from the surrounding phrases.

\section{CONCLUSION}

Though register is but one of a multitude of musical factors that go into creating a composition's tonal shape, Haydn's striking use of extreme pitches in his keyboard works displays his awareness that register can articulate formal or musical events. Especially in his keyboard works written from 1784 onward 
(though there is some precedent in his works of 1765-1783), Haydn prefers to reserve registral extremes for moments that are important to the overall musical shape of a composition. He articulates both large-scale form (thematic units) and local form (individual phrases) in this manner. Moreover, many of Haydn's uses of high and low $\mathrm{F}$ are tonality-specific. He pairs the keyboard's highest pitch with $\mathrm{V}^{7}$ harmony in $\mathrm{C}$ major compositions, with chromatic chords in $\mathrm{D}$ minor compositions, and with modal mixture in A major compositions. To be certain, the presence and location of high or low $\mathrm{F}$ in a Haydn keyboard work is a more significant contributor to tonal and formal shape than is generally acknowledged. The characteristic range of Classical keyboard instruments inspired Haydn to devise creative solutions to the use of register, solutions that often have an impact on how listeners perceive the formal unfolding of his keyboard compositions.

\section{REFERENCE LIST}

Brown, A. Peter. 1986. Joseph Haydn's Keyboard Music: Sources and Style. Bloomington: Indiana University Press.

Eitan, Zohar. 1997. Highpoints: A Study of Melodic Peaks. Philadelphia: Pennsylvania University Press.

Good, Edwin. 2001. Giraffes, Black Dragons and Other Pianos: A Technological History from Cristofori to the Modern Concert Grand. 2nd ed. Stanford: Stanford University Press.

Harrison, Bernard. 1997. Haydn's Keyboard Music: Studies in Performance Practice. Oxford: Clarendon Press.

Haydn, Joseph. 1966a. Sämtlicher Klaviersonaten. Ed. Christa Landon and Oswald Jonas. Vienna: Wiener Urtext Edition.

- 1966b. Kritische Ausgabe sämtlicher Symphonien. Ed. H. C. Robbins Landon. Vol. 11. Vienna: Universal Edition.

Komlós, Katalin. 1995. Fortepianos and their Music: Germany, Austria and England, 1760-1800. Oxford: Clarendon Press, 1995.

Libin, Laurence. 1994. "The Instruments." In Marshall 1994, chap. 1. New York: Schirmer Books.

Marshall, Robert, ed. 1994. Eighteenth-Century Keyboard Music. New York: Schirmer Books.

Oster, Ernst, 1961. "Register and the Large-Scale Connection," Journal of Music Theory 5: 54-71.

Robbins Landon, H. C. 1976. Haydn: Chronicle and Works. Vol. 3. Bloomington: Indiana University Press.

. 1978. Haydn: Chronicle and Works. Vol. 2. Bloomington: Indiana University Press.

Rosen, Charles. 1997. The Classical Style. Expanded ed. New York: Norton. . 2001. "The Benefits of Authenticity." In Critical Entertainments: Music Old and New, 201-21. Cambridge, MA: Harvard University Press. 
Rowland, David. 1999. "Piano music and keyboard compass in the 1790s." Early Music 27, no. 2 (May): 283-93.

Sisman, Elaine. 1993. Haydn and the Classical Variation. Cambridge, MA: Harvard University Press.

Somfai, László. 1995. The Keyboard Sonatas of Joseph Haydn: Instruments and Performance Practice, Genres and Styles. Trans. László with Charlotte Greenspan. Chicago: University of Chicago Press.

Sutcliffe, W. Dean. 1998. "The Haydn Piano Trio: Textual Facts and Textural Principles." In Haydn Studies, 246-90. Cambridge, UK: Cambridge Univ. Press.

\begin{abstract}
The Classical keyboard in its various forms (harpsichord, clavichord and fortepiano) typically had a modest five-octave range $\left(\mathrm{FF}-\mathrm{f}^{3}\right)$ prior to ca. 1800 . This essay examines how this range influenced the tonal shape of Joseph Haydn's keyboard music written after 1765. The author explores how Haydn used registral extremes to emphasize major formal junctures, cadences and modulations. Finally, he explores how the presence or absence of the keyboard's extreme pitches contributes to key character, examining the different contexts in which Haydn uses them in three tonalities: $D$ minor, $C$ major and $A$ major.
\end{abstract}

\title{
Résumé
}

Avant environ 1800 , les différentes formes d'instruments à clavier classiques (clavecin, clavicorde et pianoforte) comportaient un modeste ambitus de cinq octaves (de deux octaves et demie sous le do central à $f a$ deux octaves et demie au-dessus du do central). Le présent essai analyse comment cet ambitus influe sur le contour tonal de la musique pour clavier de Joseph Haydn, écrite après 1765. L'auteur démontre comment Haydn utilisait les extrémités du registre pour mettre en relief les principaux points de jonction formels, les cadences et les modulations importantes. Enfin, il signale comment la présence ou l'absence des hauteurs extrêmement graves ou aiguës du clavier contribue à accentuer le caractère de la tonalité. Pour ce faire, il étudie différents contextes dans lesquels Haydn les emploie : ré mineur, do majeur et la majeur. 